\title{
Analysis on Potential Strategic Warfare in the Arctic from the View of Game Theory
}

\author{
Yuncong Sun \\ Department of Aviation Ammunition \\ Air Force Logistics College \\ Xuzhou, Jiangsu, China 221000
}

\author{
Hua Wan \\ Department of Aviation Ammunition \\ Air Force Logistics College \\ Xuzhou, Jiangsu, China 221000
}

\begin{abstract}
The article describes the status quo of arms race increasingly hot in the Arctic and analyzes the current situation in the Arctic on the basis of the model of Prisoner's Dilemma and Security Dilemma in the game theory as well as the warfare theory.
\end{abstract}

\section{Keywords—arms race; game theory; warfare theory}

\section{INTRODUCTION}

Going with the global warming and ice melting, the strategic position of the Arctic is being raised continuously, and the huge resource potential has made it possibly be a hot region for the large-scaled economic activities by human being, and the air lines in the Arctic may become a corridor to control the world economy ${ }^{[1-2]}$. Relying on the huge economic value, important military position and significance to the global trade situation, the Arctic is gradually becoming a region where the countries around the world compete for development, besides, the United States, Canada, Norway and other countries, having territorial claims on the Arctic, have accelerated the pace to the Arctic and scrambled in the region. As a result, the northernmost end of the Earth has been earlier than the southernmost end to change from "the time of scientific investigation" to "the time of geopolitical disputes".

In 2009, Russia proposed a plan to set up a special operation brigade in the Arctic, and announced to establish the first motorized infantry brigade there in 2015. In order to take the lead to develop the Arctic, in Jun 2016, the world's largest nuclear-powered icebreaker built in Russia was launched. Besides, In order to defend the northern border, the Russian Department of Defense also intended to set up 20 frontier stations, aiming to monitor the situation in the Arctic, and deploy two Arctic combat brigades in the future. Lately, it was reported that the world's first floating nuclear power plant" Akademik Lomonosov" built in Russia would enter the waters of Denmark in 2017 so as to open a journey to the Arctic. Similarly, the United States also did not reduced military operations in the Arctic Ocean, and increased the activities of nuclear-powered submarines and deployed spy satellites to span on the activities of Russia in the Arctic Ocean and drew more NATO countries to participate in the containment against Russia. Starting from the year of 2007, Canada held an "Operation Nanook" military exercise ${ }^{[3]}$ every year in the Arctic, in 2009 Canada declared to build the Arctic Army
Corps. "Putin can not decide who owns the Arctic," Canadian Prime Minister Trudeau made such a statement in Mar 2016.

The countries around the Arctic strengthen the military presence in the Arctic and fight for resources and interests there, which not only seriously affect the peace and stability of the region ${ }^{[4]}$, but also threaten the interests of non-Arctic countries such as China in the region.

\section{GAME THEORY AND WARFARE THEORY}

\section{A. Game Theory}

Game theory is a subject and theory studying competitiveness, aiming at analyzing the decisions on the interaction of behaviors of decision-makers and relevant balances. Initially the game theory adopted mathematical methods to study whether there were optimal strategies and how to find them for one party to defeat the other with interests in competitive actions (as war). As a new tool for interpreting the history, the game theory has been regarded increasingly in modern life.

Theoretical premise for the game theory model is to assume that the game participants are "rational" people. This article will analyze two countries, among which, actions such as deterrence and counter deterrence, retaliation and counterretaliation, limited war, arms race, border policy, raids, attacks and fraud are all considered rational behaviors. According to the rational behavioral model, the traditional theory of realist international relations assumes that the state is an independent actor, which can take rational behaviors, and calculate the benefits and costs by different strategies so as to find measures to maximize utilities.

\section{B. Warfare Theory}

Strategy is related to the fate of a country and it is "a way of survival". The idea and guiding ideology for wars are "based on damages" and the first goal is to destroy, consume and demolish the enemy, which has been developed to achieve some kind of "effect" in modern wars. Western countries propose an "effect-based" operational thinking, and the Americans call the revaluation in the war concept a new philosophy of war. The "Based on the effect" means to control the whole combat system of the enemy and seize strategic advantages so as to deprive it of combat capabilities. The 
warfare $^{[5]}$, also known as strategic warfare, is just based on the performance of effect, seen from the game, it is a dynamic game process in nature. The significance of the warfare is to achieve a strategic combat effect the same as military attack through deterrence and containment.

In nature, the (two or more) parties of warfare are rational actors, and the strategies of their own must depend on that of other parties. Differing from general tactics or campaigns aiming at defeat, the warfare aims at peace or a situation, namely a balance to some degree. Under the sound international order, the game in warfare is a cooperative game with incomplete information; under a confused international order and power politics, the warfare is a generally noncooperative game with incomplete information. Seen from the significance of national defense, more attentions should be paid to the warfare through non-cooperative game with incomplete information. Actually the development from cold war to hot war is a course from cooperation to game, which is an embodiment of games in multiple stages.

The strategy here is related only to deterrence by force but not to the use of force. In addition, the parties in the game are not enemies who are not completely irreconcilable but partners with doubts and disputes. It focuses on not the gains or loss of the parties concerned but how to reach a result to achieve the maximum benefits of the two. In terms of the game theory, the most interesting international conflict is not zero-sum game but a non- zero-sum game. As for the latter, the loss of a party in the game do not means gains of the other, for both parties in the game, to achieve a win-win result is a common interest for them.

The purpose of strategic warfare is to seize the command of strategy, B. H. Liddell Hart pointed out: "the true purpose of a strategist is to not only seek opportunities for battle (fight) but also form a most advantageous strategic situation." The command of strategy is just aiming to influence and restrict the strategic decisions of other countries through the establishment and implementation of state strategies so as to form an advantageous situation and further master the strategic initiative, establish the discourse power of a country or region and better safeguard the state security and development benefits. It can be said that the strategic warfare is to achieve an advantageous situation through seizing the command of strategy.

Guided by military theories in the information-based social conditions, the course and trend of warfare are often confusing. And the thought of independence and pursuit of cooperation and development will inevitably lead to Nash equilibrium; to seek expansion and seize the interests of resources will break the balance. During the game, new conditions such as negotiation and treaty will be used by and between countries to a new balance.

\section{ANAlysis Of WARfare In The GAME In ThE ARCTIC}

Suppose both county $\mathrm{X}$ and country $\mathrm{Y}$ have a warfare situation, both facing a difficulty in expansion and restriction in the current international situation, the expansion makes it advantageous to seize international interests and command of strategy, the restriction may save resources and reduce the expenditure in national defense. In the game in the Arctic, the actions the countries have adopted to seize the interests in the Arctic such as Arctic strategy, deployment of military force, more military existence, military exercises, scientific investigation and so on are all strategies of expansion, otherwise the contrary are that of restriction.

The problem can be indicated through the Prisoner's Dilemma model, the benefits herein refer to gains of countries in the Arctic "Table I".

TABLE I. THE GAINS AND DAMAGES OF COUNTRIES BY EXPANSION AND RESTRICTION

\begin{tabular}{|l|l|l|}
\hline Country X & Expansion & Restriction \\
Country Y & & \\
\hline Expansion & 80,80 & 90,70 \\
\hline Restriction & 70,90 & 85,85 \\
\hline
\end{tabular}

If country $\mathrm{X}$ and country $\mathrm{Y}$ both select expansion, as strengthening military force in the Arctic, the two will obtain gains of 80 ; if the country $\mathrm{X}$ selects expansion, the country $\mathrm{Y}$ will select restriction, as such, the country $X$ will obtain more gains and higher security in the Arctic, and the interest of the country $\mathrm{Y}$ will be damaged, indicated as $(90,70)$; if the country $\mathrm{Y}$ selects expansion, the country $\mathrm{X}$ will select restriction, just like what mentioned above, indicated as $(70,90)$; if both country $\mathrm{X}$ and country $\mathrm{Y}$ select restriction, the two parties will make a peaceful use of resources in the Arctic and enjoy higher security degree, but the gain of each country is not higher just like the condition where a country selects expansion and other selects restriction, indicated as $(85,85)$.

As for the game, according to the definition of Nash equilibrium, through the "elimination of strictly dominated strategy" method, the Nash equilibrium point in the game can be obtained as $(80,80)$, namely both select expansion. Though both may obtain better results (gains of 85 for both parties) after selecting the restriction, yet suppose a party selects restriction, the gains of the other party selecting expansion will be higher, no doubt a rational country will not select the restriction, it is called Prisoner's Dilemma, it proves why the countries fall over each other to size but refuse cooperation for win-win with the value of the Arctic emerging.

The Security Dilemma in arms race may better proves the game $^{[6]}$, of which, the expansion in armament is so-called expansion, to give up the armament is so called restriction. Specifically, the parties cooperating with each other (no military expansion) may obtain encouraging returns (both have no military expansion with higher security degree and reduced military expenditure), which is higher than the returns to both parties in case of no-cooperation (both have military expansion without cooperation). However, both are envious of induced returns (having advantages over the other in military), which is the highest benefits obtained after selecting betrayal strategy. Meanwhile, both are afraid of being a victim trampled by the other due to no betrayal, obtaining the simple return (being a country without military expansion). During a period of crisis, the allurement of military expansion is almost hard to resist. 
Each country is afraid of being a victim in a sudden attack by the other, which was called "Interactive horror to sudden attacks" by Thomas C. Schelling ${ }^{[7]}$, the essence of the problem is, others, thinking wrongly we will firstly attack it, firstly attack us, so we have to firstly attack the others. Accordingly some propose a forestalling war, the reasons for attack originate from the doubts between each, and the lack of credit between each is an essential characteristic for the problem.

In the issue of the Arctic, the strategic warfare has been vividly embodied in the "Prisoner's Dilemma" game. In 2007, after Russia planted an undersea flag in the Arctic, Canada quickly launched an "Operation Nanook" military exercise as response; Prime Minister Stephen Harper visited the military exercises and proposed two new military facilities in the Arctic, including a deep water port and a military training center. The exercise has also become an annual military exercise in the Arctic. Facing the military presence increased by Russia with billions of dollars investment close to Norway, Norwegian Prime Minister Jens Stoltenberg said that Norway would continue and strengthen its military power in the Arctic, and maintain high level investment in the promotion of military capabilities. Norway has sought a closer military cooperation with NATO to enhance the alliance in the Arctic region. Although Russia said its Arctic strategy had no intention of militarizing the Arctic, yet it is inevitable for militarization in the Arctic, and the security dilemma between the countries concerned may trigger wars, making the Arctic development a bubble.

\section{CONCLUSION}

If such arms races continue out of control, the Arctic environment and human security will be in a dangerous situation. Peace and development have become a mainstream of the world, to avoid extreme behaviors in competition should be a bottom line of the game among major countries in the world, which should make a right strategic choice on the basis of geographical position and comprehensive strength of their own. To deal with the issue of the Arctic, the countries concerned may refer to that of the Antarctic, respect each other, negotiate peacefully and coexist peacefully on the basis of democracy in international relations. The most important is to set up and improve an international law to govern the Arctic or the Arctic Ocean as a whole, and establish effective and powerful international organizations or invite the United Nations to deal with it.

\section{REFERENCES}

[1] Hobér, K. Territorial disputes and natural resources: the melting of the ice and Arctic dispute.Oil, Gas \& Energy Law Journal (OGEL), 10(2).http://www.ogel.org/article.asp?key=3245, 2012

[2] Mendez, T. Thin ice, shifting geopolitics: the legal implications of Arctic ice melt. Denver Journal of International Law and Policy, 38, 527-547, 2009

[3] Shamil Midkhatovich Yenikeyeff, Yimothy Krysiek. The Battle for the Next Energy Frontier: The Russian Polar Expeditionand the Future of Arctic Hydrocarbons. Oxford Energy Comment, August, 2007.

[4] Zhenfu Li, Jianping Sun. Analysis of Criterion Game Mechanism of Arctic Route Geopolitical. World Regional Studies, Vol.20, 2011, pp.56-62
[5] Fengshan Wang, Maoxing Shen. Researches on Modeling the Potential Warfare Law of Air Defense Strategy. Journal of Air Force Engineering University(Natural Science Edition), Vol.1, 2000, pp.80-82

[6] Xiaoyan Zhang. Analysis on the Self-coordination during the Cold War from the Perspective of Game Theory. Journal of Daqing Normal University, Vol.29, 2009, pp.44-47

[7] Thomas C. Schelling. The strategy of conflict. Oxford University Press, 1980. 